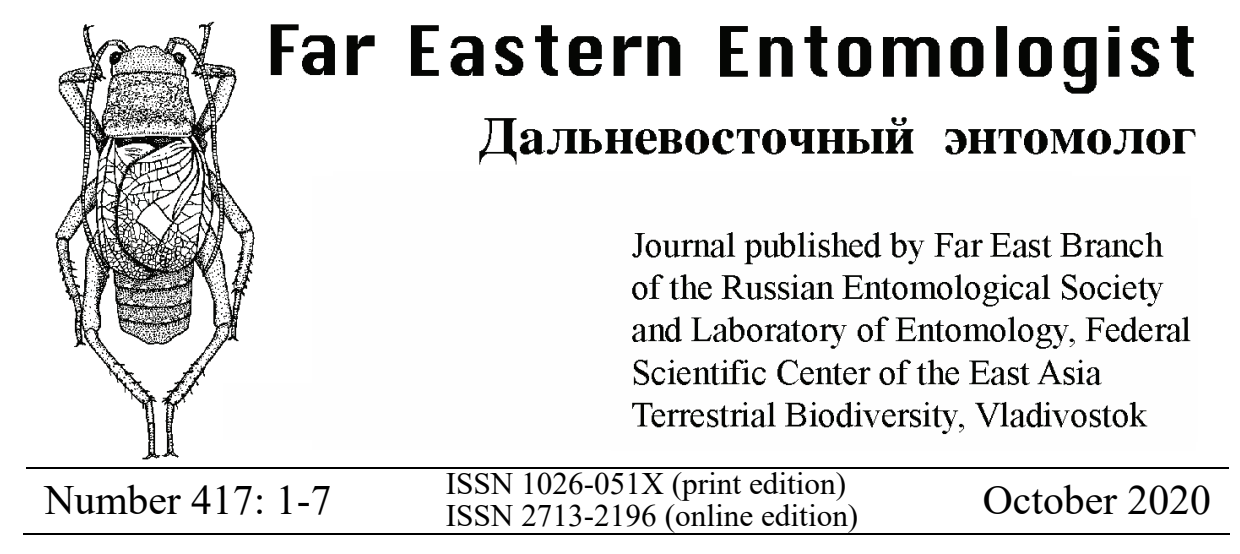

https://doi.org/10.25221/fee.417.1

http://zoobank.org/References/F570DB4F-9AF2-4989-BEAB-42C35BB7B647

\title{
NEW SPECIES OF THE GENUS EUMERUS MEIGEN, 1822 (DIPTERA: SYRPHIDAE) FROM CENTRAL ASIA
}

\section{A. V. Barkalov"), V. A. Mutin ${ }^{2, ~ *), ~ D . ~ B . ~ D a m i n o v a ', ~}$ M. R. Rakhimov ${ }^{4}$}

1) Institute of Systematics and Ecology of Animals, Russian Academy of Sciences, Siberian Branch, Frunze str. 11, Novosibirsk, 630091, Russia. E-mail: bark@eco.nsc.ru

2) Amur State University of Humanities and Pedagogy, Kirova str. 17/2 Komsomolsk-na-Amure, 681000, Russia. *Corresponding author, E-mail: valerimutin@mail.ru

3) Institute of Zoology Academy of Sciences of The Republic of Uzbekistan, Bagishamol str., 232b, Tashkent, 100053, Uzbekistan.

4) Samarkand State University, University blvd. 15, Samarkand, 140104, Uzbekistan. E-mail: muhammadtuychi@gmail.com

Summary. Eumerus bilobatus sp. n. is described from Uzbekistan and Turkmenistan. The new species belongs to the bactrianus subgroup of the strigatus species group of the genus Eumerus Meigen, 1822 (sensu Grković et al., 2019). It is most similar to E. bifurcatus van Steenis et Hauser, 2019 but differs from latter in yellow hairs on ocellar triangle, shorter ventral hairs on hind femur, narrowly yellow-brown tip of tergite IV as well as in the structure of the male genitalia (in E. bifurcatus, ocellar triangle with black hairs, ventral hairs on hind femur 3-5 times longer than dorsal hairs, and tergite IV completely black).

Key words: hover flies, Syrphidae, taxonomy, new species, Palaearctic Region. 
А. В. Баркалов, В. А. Мутин, Д. Б. Даминова, М. Р. Рахимов. Новый вид рода Eumerus Meigen, 1822 (Diptera, Syrphidae) из Центральной Азии // Дальневосточный энтомолог. 2020. N 417. С. 1-7.

Резюме. Из Узбекистана и Туркменистана описан новый для науки вид Eumerus bilobatus sp. n. Этот вид относится к видовой подгруппе bactrianus группы strigatus рода Eumerus Meigen, 1822 (sensu Grković et al., 2019). Новый вид близок к E. bifurcatus van Steenis et Hauser, 2019, но хорошо отличается наличием жёлтых волосков на оцелярном треугольнике, менее длинными вентральными волосками на задних бёдрах, наличием жёлто-коричневой полосы на заднем крае IV тергита и иным строением гениталий самцов (у $E$. bifurcatus волоски на оцелярном треугольнике чёрные, нижние волоски на задних бёдрах в 3-5 раз длиннее верхних и IV тергит полностью чёрный).

\section{INTRODUCTION}

The genus Eumerus Meigen, 1822 is one of the largest genera of the hover flies in the Palaearctic Region (Grković et al., 2019). In terms of its ecological preferences, the genus gravitates towards southern limits of the Palaearctic, since the larvae of its species develop in the bulbs and other succulent organs of plants, and some being known as pests of cultivated plants (Pérez-Bañón \& Marcos-García, 1998; Ricarte et al., 2017). There are some distinct species-groups within the genus. Here, we describe the new species from the strigatus group, bactrianus subgroup (sensu Grković et al., 2019). Species of this subgroup differ from others members of the group by bifurcated surstylus.

\section{MATERIAL AND METHODS}

The description is based on the materials collected by D.B. Daminova and M.Yu. Proshchalykin in Uzbekistan and by A.V. Barkalov in Turkmenistan.

Male genitalia were dissected and prepared for study following Hippa (1968). All drawings were prepared with the aid of an ocular grid and graph paper. The photographs were taken with a Canon EOS 600D attached to Zeiss Stemi-2000 stacked with Helicon Focus, as well as with the steriomicroscope ZEISS SteREO Discovery V12 and digital camera AxioCamMRc, and stacked using CombineZM.

The following abbreviations are used for the deposition of type material discussed in this study:

DBD - private collection of D.B. Daminova, Tashkent, Uzbekistan;

FCBV - Federal Scientific Center of East Asia Terrestrial Biodiversity, Vladivostok, Russia;

SSU - Entomological collection of the Samarkand State University, Samarkand, Uzbekistan;

SZMN - Siberian Zoological Museum, Institute of Systematics and Ecology of Animals, Novosibirsk, Russia. 


\section{DESCRIPTION OF NEW SPECIES}

Eumerus bilobatus Barkalov, Mutin, Daminova et Rakhimov, sp. n.

http://zoobank.org/NomenclaturalActs/0F82D42F-C5B4-4932-9B6D-A3BD92433BFC

Figs $1-12$

TYPE MATERIAL. Holotype - $\widehat{\jmath}$, Turkmenistan: vicinity of Ashgabat City, Firuza settlement, 23.IV 1987, A. Barkalov leg. [SZMN]. Paratypes (20 specimens): Turkmenistan: $15 \mathrm{~km}$ west of Firuza settlement, Dushak Mountain, 4-11.V 1987, 6 $๊, 8$ q, A. Barkalov leg. [SZMN]; Uzbekistan: Nuratau Nature Reserve, Hayatbashi Mountine $40,49895^{\circ} \mathrm{N}, 66,72956^{\circ} \mathrm{E}, 17 . \mathrm{VI} 1997,1$ đ, D. Daminova leg. [SZMN]; Nuratau Nature Reserve, Hayat Valley $40,518950^{\circ} \mathrm{N}, 66,749560^{\circ} \mathrm{E}, 5 . \mathrm{V}$ 1995, 1 $\curvearrowright$, D. Daminova leg. [DBD]; Nuratau Nature Reserve, Andibarout valley,

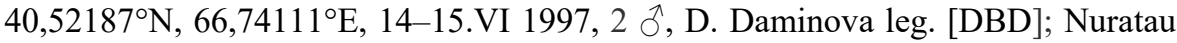
Nature Reserve, Alichak valley, 40,508612 ${ }^{\circ} \mathrm{N}, 66,739324^{\circ} \mathrm{E}, 28 . \mathrm{VI} 1995,1$ ๙ , D. Daminova leg. [SSU]; Qarshi, 19.V 2015, 1 ते, M. Proshchalykin leg. [FCBV]; Darband, 10.V 2015, 1 क , M. Proshchalykin leg. [FCBV].

DESCRIPTION. MALE. Body length 6.5-7.3 mm, wing length 5.0-6.5 mm.

Head. Face and frons with dense silver dusting and white hairs. Eyes holoptic, with very short sparse white hairs; line of their connection a little bit shorter than the length of frons (Fig. 5). Vertex shiny black, with white or yellow hairs, with spots of grey dusting on hind margin near eyes; ocellar triangle isosceles, with white hairs. Occiput broad, shiny, with white hairs. Antennae: scapus and pedicel black, latter with narrow yellow rim, short black dorsal hairs and long white ventral ones; postpedicel oval (Fig. 7) and entirely black or irregular form with antero-ventral angle (Fig. 8), mainly dark-brown to black except reddish baso-lateral spot, with dense silver dusting.

Thorax. Postpronotum shiny black with white hairs. Scutum shiny black, with two narrow sub-medial stripes of grey dusting on anterior half and dusting spots on sides which don't reach postalar calli, mainly with short erect white hairs except row of short strong black bristles on lateral margin before postalar callus. Scutellum distinctly margined, shiny black, with white hairs longer on hind margin. Pleura shiny black with fine white dusting and white hairs, postero-dorsal part of katepisternum and katatergum glossy shiny.

Legs. Coxae black with white hairs, fore coxa with reddish tip; femora black with yellow bases and tips; hind femur moderately swollen, without any process or knobs, with short black bristles ventrally (Fig. 10); tibiae without any process, reddishyellow on basal half and apex, and black or brown on apical half; hind tibia with a row of short addressed black bristles on basal third; tarsi simple, not broadened not swollen, yellow ventrally, fore tarsus blackish dorsally, mid tarsus yellow with blackish segments 4-5, hind tarsus mainly reddish-brown except dorsal surface basitarsus and segments 4-5 blackish; segments 1-4 of mid tarsus with short black bristles ventrally. Wings hyaline without dark spots. Squama white, halter yellow. 
Abdomen. Parallel-sided, as wide as scutum, black with fine bluish reflection; tip of tergite IV narrowly yellow-brown; tergites II-IV with oblique grey spots (Fig. 1-2); sides of tergites I-III and hind half of tergite IV with short white hairs, middle part of all tergites with depressed short black hairs. Sternites black, sternite V with broad shallow notch. Hypopygium - as in Figs 11, 12.
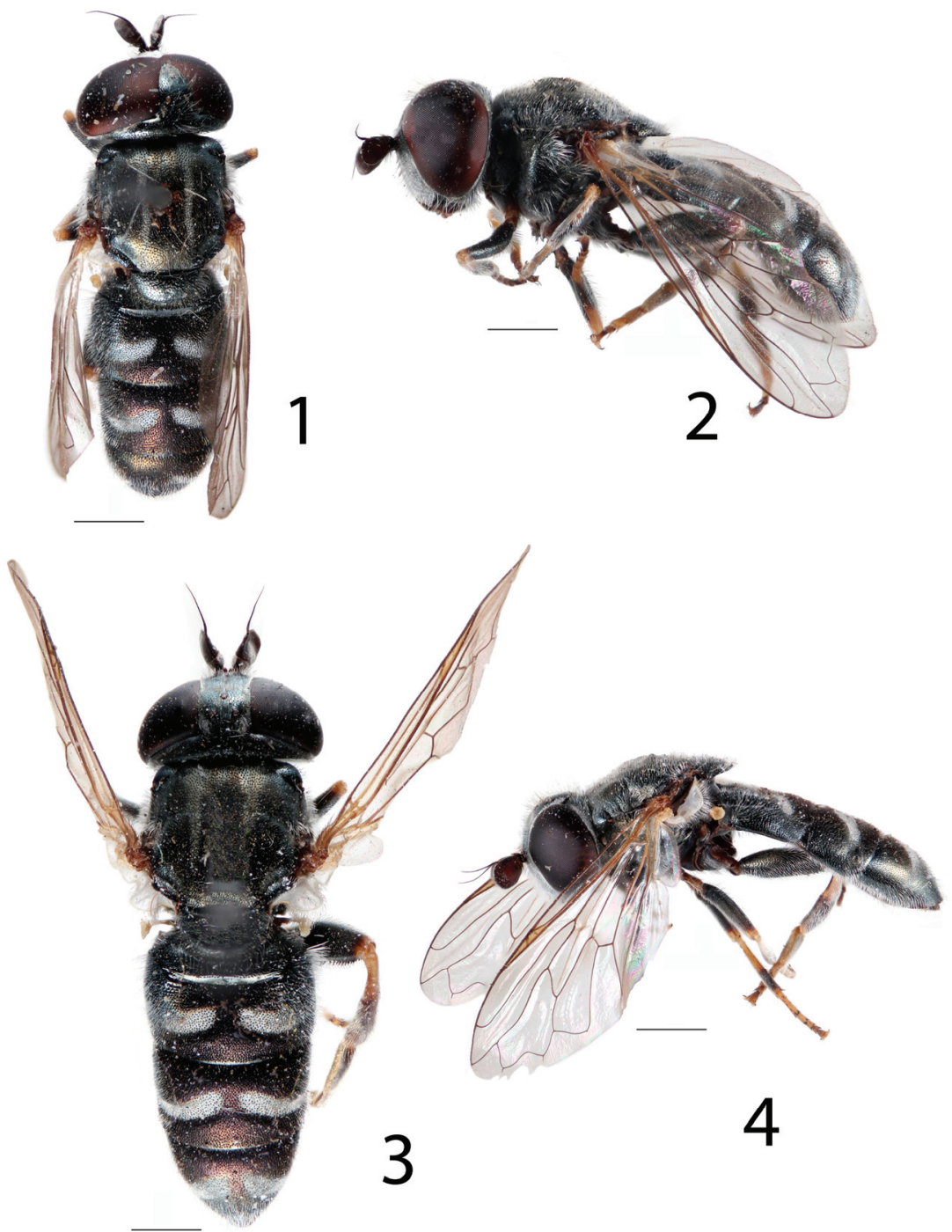

Figs 1-4. Eumerus bilobatus sp. n. 1 - male dorsally; 2 - male laterally; 3 - female dorsally; 4 - female laterally. Scale bars $1 \mathrm{~mm}$. 
VARIABILITY. The form and coloration of postpedicel vary from oval (Fig. 7) and completely black (in some specimens from Turkmenistan) to irregular with antero-ventral corner (Fig. 8) and big orange-reddish spot in the middle (specimens from Uzbekistan). Sub-medial stripes of grey dusting on scutum can be distinctly seen only in its anterior1/3. Tergite IV of one male from Turkmenistan reddishbrown on sides and black in the middle (a narrow reddish stripe on posterior margin in other specimens).

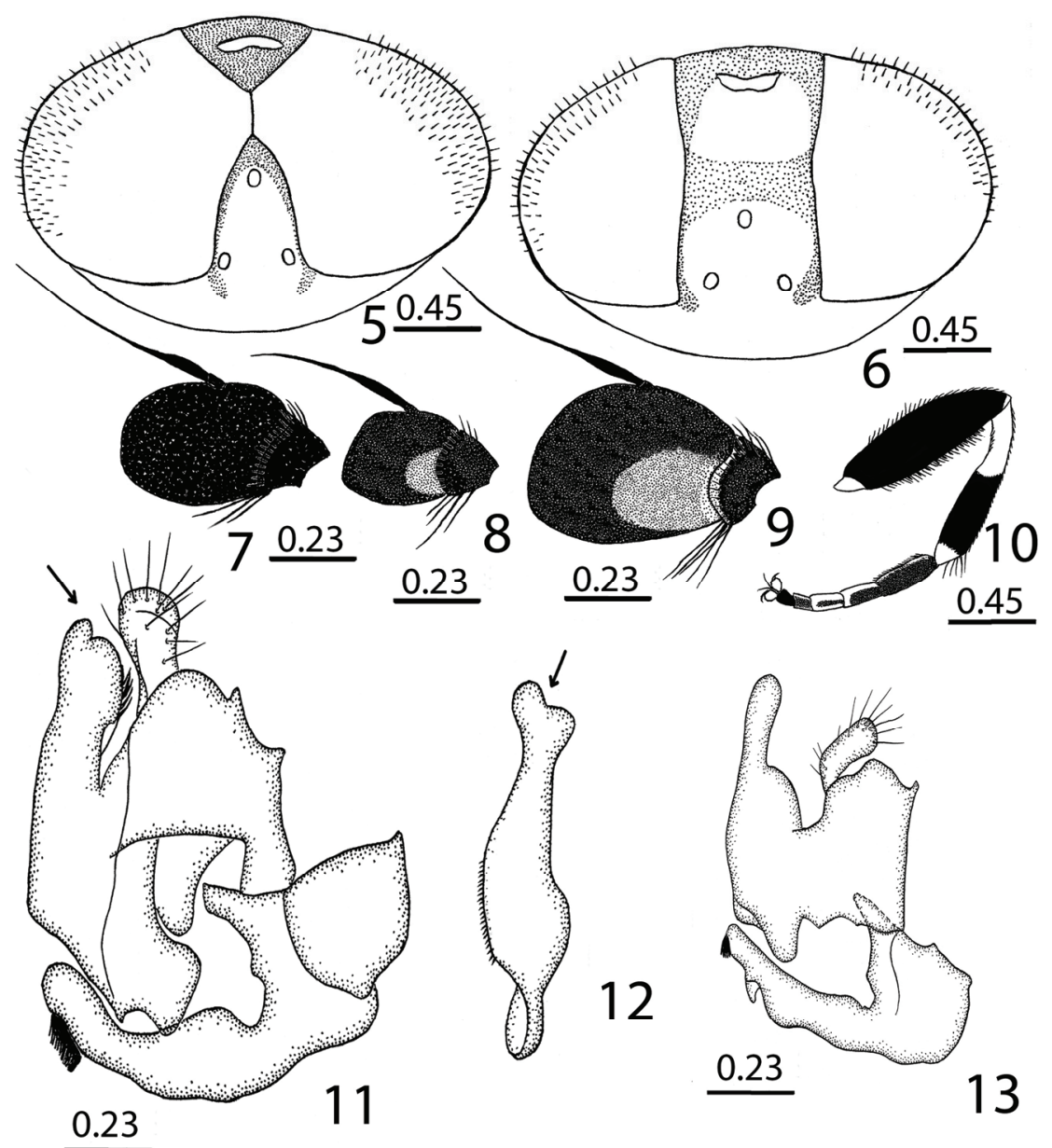

Figs 5-13. Eumerus ssp. 5-12 - E. bilobatus sp. n.: 5- head of male dorsally; 6 - head of female dorsally; 7-8 - male pedicel and postpedicel laterally; 9 - female pedicel and postpedicel laterally; 10 - hind leg of male, anteriorly; 11 - male genitalia laterally; 12 surstylus anteriorly; $13-$ E. sogdianus Stack., male genitalia laterally. Scale bars in $\mathrm{mm}$. 
FEMALE. Body length 7.2-8.5 mm, wing length 6.3-6.6 mm.

Similar to male except the characters of sexual dimorphism (Figs 3, 4). Postpedicel bigger than that of the male, black outside and with big reddish-brown medial spot inside (Fig. 9). Frons comparatively narrow (Fig. 6) with narrow stripe of grey dusting near eye margin and transverse stripe of grey dusting varying in width. Ocellar triangle equilateral (Fig. 6). Tergite IV black either with very narrow reddish-brown stripe on posterior margin or completely black.

DIAGNOSIS. In key to Palaearctic species of the genus Eumerus (Stackelberg, 1961) males of new species with blackish postpedicel goes to Eumerus sogdianus Stackelberg, 1952 but distinctly differ from latter by bifurcated surstylus (Figs 11, 12 vs. Fig. 13). In the same key specimens with big orange-reddish spot on postpedicel goes to E. acuticornis Sack, 1933, but differs from it by blackish dorsally fore tarsi and by partly blackish postpedicel (in E. acuticornis yellow fore tarsi and light red postpedicel).

In the key to European species of the bactrianus species subgroup (Grkovic et al., 2019) E. bilobatus sp. n. goes to E. bifurcatus van Steenis et Hauser, 2019. The new species well differs from $E$. bifurcatus by yellow hairs on ocellar triangle, shorter ventral hairs on hind femur, tergite IV with narrow yellow-brown tip and by different structure of the male genitalia (in E. bifurcatus ocellar triangle with black hairs, ventral hairs on hind femur 3-5 times longer than dorsal hairs, and tergite IV completely black).

DISTRIBUTION. Uzbekistan and Turkmenistan.

ETYMOLOGY. The species is named because of the two-lobed form of surstylus.

\section{ACKNOWLEDGMENTS}

The study was supported by the Russian Foundation for Basic Research (grant № 20-04-00027-a) and the Federal Fundamental Scientific Research Programme for 2013-2020 (AAAA-A16-116121410121-7). We are grateful to G.N. Azarkina for making photographs. M.R. Rakhimov sincerely thanks of M.G. Nasyrov for help in the work.

\section{REFERENCES}

Grković, A., van Steenis, J., Kočiš Tubić, N., Nedeljković, Z., Hauser, M., Hayat, R., Demirözer, O., Đan, M., Vujić, A. \& Radenković, S. 2019. Revision of the bactrianus subgroup of the genus Eumerus Meigen (Diptera: Syrphidae) in Europe, inferred from morphological and molecular data with descriptions of three new species. Arthropod Systematics and Phylogeny, 77(1): 21-37. DOI: https://doi.org/10.26049/ASP77-1-201902

Hippa, H. 1968. A generic revision of the genus Syrphus and allied genera (Diptera, Syrphidae) in the Palearctic region with descriptions of male genitalia. Acta Entomologica Fennica, 25: $1-94$.

Pérez-Bañón, C. \& Marcos-García, M.A.1998. Life history and description of the immature stages of Eumerus purpurariae (Diptera: Syrphidae) developing in Opuntia maxima. European Journal of Entomology, 95: 373-380. 
Ricarte, A., Souba-Dols, G.J., Hause, M., Marcos-García, M.A. 2017. A review of the early stages and host plats of the genera Eumerus and Merodon (Diptera, Syrphidae), with new data on four species. PLoS ONE, 12(12): e0189852. DOI: https://doi.org/10.1371/ journal.pone. 0189852

Sack, P. 1933. Syrphidae. Schwedisch-chinesische wissenschaftliche Expedition nach den nardwestlichen Provinzen Chinas, unterLeitung von Dr. Sven Hedin und Prof. Sü Pingchang. Arkiv för Zoolgi, 26(1) 6: 1-9.

Stackelberg, A.A. 1952. Novye Syrphidae (Diptera) paearkticheskoy fauny. Proceedings of the Zoological Institute, Leningrad, 12: 350-400. [In Russian]

Stackelberg, A.A. 1961. Palaearctic species of the genus Eumerus Mg. (Diptera, Syrphidae). Horae Societatis Entomologicae Unionis Soveticae, 48: 181-229. [In Russian] 